\title{
HISTOPHYSIOLOGICAL CHANGES OF THE TESTICULAR TISSUE DUE TO BUSULPHAN ADMINISTRATION IN THE WILD INDIAN HOUSE RAT (RATTUS RATTUS)
}

\author{
S. Aich and C. K. MANNA* \\ Endocrinology Laboratory, Department of Zoology, University of Kalyani, \\ Kalyani 741235, Nadia, West Bengal, India \\ (Received: June 15, 1999; accepted: October 5, 1999)
}

\begin{abstract}
The results of the present study indicate the antispermatogenic activity of Busulphan or Myleran (1,4dimethane-sulphonoxy butane) on the testicular tissue of adult male Indian house rat, Rattus rattus. Single oral dose of Busulphan $(10 \mathrm{mg} / \mathrm{Kg}$ body weight $)$ was administered and its activity was noticed at $10,40,70$ and 100 days of posttreated animals.

Histological observation and quantitative histological study indicates no major alteration in the relative percentages of primary spermatocytes, spermatid and Sertoli cells at 10 days of posttreatment. But there was a gradual decrease in the seminiferous tubular diameter at 40 and 70 days of post treated groups. However, the Leydig and Sertoli cells morphology and number remained normal in all the treatment groups. At 40 days, the normal cellular associations in all the tubules were disrupted. The tubules constituted only spermatogonia, Sertoli cells and some zygotene spermatocytes. At 70 days, repopulation of Type A, Type B spermatogonia, resting and zygotene spermatocytes occurred at this stage. The tubules were still devoid of pachytene spermatocytes, spermatid and spermatozoa. At 100 days, active spermatogenesis was observed in majority of the tubules. The various types of germ cell population were regaining towards normalcy.

Histochemical studies clearly revealed that due to busulphan administration there was no major alteration in the intensities of some key enzymes (i.e. $\Delta 53 \beta-\mathrm{HSDH}$ and $17 \beta-\mathrm{HSDH}$ ) involved in the biosynthesis of steroid hormones. Only the acid phosphatase activity was slightly depressed within the 40th and 70th days of posttreatment. Sudanophilic lipid materials increased in the interstitium of all the busulphan post treated groups. The changes which were noticed due to busulphan treatment regained normalcy at 100 days of post treated animals

The mode of action of Busulphan on the testicular tissue of adult Indian house rat (Rattus rattus) has been pointed out and discussed.
\end{abstract}

Keywords: Bisulphan - spermatogenetic activity - histology - rat

\section{INTRODUCTION}

The antispermatogenic properties of one member of the group of alkane sulphonic esters, 1,4-dimethane-sulphonoxybutane, commonly known as Busulphan (Myleran) is well establised in various mammalian and avian species. It has been recorded that

\footnotetext{
* Corresponding author; E-mail: manna@klyuniv.ernet.in
} 
single injection (i.p.) of Busulphan (10 $\mathrm{mg} / \mathrm{kg}$ body wt.) in male rats, rabbits and mice led to induction of infertility after 8 weeks of treatment $[10,12,13]$, associated with progressive destruction of seminiferous epithelium [5] and spermatogonial damage $[14,19]$.

While several aspects of Busulphan on spermatogenesis of some mammalian and avian species have been studied, and the possible mode of action has been pointed out by some authors, but there is no detailed and systematic investigation on the variable dose response of this sulphonic ester on the testicular tissue of the wild murid rodents. From the earlier reports it is noted that due to the high rate of breeding performance and carrier of dreaded germs, the reproductive efficacy should be controlled in a scientific way. Considering all aspects and especially to control their fertility the present study has been undertaken to pin point the site of action of this chemosterilant (Busulphan) on the spermatogenic cells within the testis at various periods of exposure in a wild murid rodent, the wild Indian house rat (Rattus rattus).

\section{MATERIALS AND METHODS}

The experiment was conducted on the adult healthy male Indian house rat, Rattus rattus. A total of twenty-five male wild rats were captured from various unprotected godowns, grocery shops around Kalyani University Campus, Kalyani, Nadia, W. B., India. After capturing they were kept singly in especially designed wire cages, measuring $60 \times 30 \times 30 \mathrm{~cm}$. The animals were acclimatized in the laboratory conditions (with 12L : 12D) for 7 days before they were used in the experiments. All the animals were provided with sufficient specially prepared rat food and water throughout the experimental period.

A total of five animals were randomly assigned to each of the five treatment groups. Group A, served as the control and Groups B, C, D and E were meant as the treated groups. All the experimental groups (B to E) received Busulphan at a dose of $1 \mathrm{mg} / 100 \mathrm{gm}$ body weight in the form of small food cube. At the termination of the experiments, at 10, 40, 70 and 100 days of post-treatment, all the animals were killed after mild ether anaesthesia and decapitation.

At the termination of the experiment body weights of individual rat of all the experimental groups were recorded. At the time of autopsy the testes and other organs of interest were quickly dissected out, weighed and fixed in aqueous Bouin's solutions for regular histological examination. The Bouin's fixed tissues were processed and sections were prepared at six $\mu \mathrm{m}$ in thickness. All the sections were stained by PAS-haematoxylin, Masson's trichrome and Cason's trichrome procedure. From the well-stained sections observations were made and photomicrographs were taken. Various histometric parameters e.g. a) Seminiferous tubular diameter; b) Leydig cell nuclear diameter and c) spermatogenetic index (the relative percentage of the tubular sections containing most advanced germ cells) were used for the quantitative histological study. The spermatogenetic index was based on the reports of Patzner [28]; Patzner and Ichikawa [29] and Maitra and Ghosh [22]. All the histo- 
metric data were recorded, calculated and analysed statistically by Students's $t$-test procedure [9].

Just after autopsy, portion of the right testis was quickly frozen in the cryocut chamber, maintained at $-18{ }^{\circ} \mathrm{C}$. After proper thawing, serial sections of the testis were prepared ( $15 \mu \mathrm{m}$ in thickness) and fixed on the greese free slides for various cytochemical procedures. After sectioning the slides were kept at room temperature for half an hour and were processed for the localization of neutral lipids [21]; Acid phosphatase [4]; Alkaline phosphatase [6]; $\Delta^{5} 3 \beta$-HSDH [35], and modified by [3] and $17 \beta$-HSDH [30], and modified by [3]. Studies were made from the well-stained sections of the control and treated groups and were carefully recorded.

\section{Libido test}

Separate experiments were conducted to assess the libido and sperm insemination capacity in the treated male rats. The antifertility effect of Busulphan was investigated by mating the treated males with the normal receptive female on selected days of post-treatment.

\section{OBSERVATIONS}

\section{Gravimetry}

Changes in the weight of the body, reproductive, accessory reproductive and other organs of interest have been presented in the Table (Table 1). There was no significant change in the body weight of the treated animals but the reduction in testicular epididymes and vas deferens weight were noticed especially in the 40 days $(\mathrm{P}<.001)$ and 70 days post-treated animals. The organ weights, e.g. testes and epididymes had returned to control values by day 100 .

\section{Histology}

Spermatogenic profile

CONTROL. Histological observations of the control testis showed normal features with successive stages (spermatogonia, spermatocytes, spermatid and mature sperms) of transformations of the seminiferous epithelium into spermatozoa. Each section revealed tubules at various stages (14 stages in Rattus $\mathrm{sp}$.) of spermateleosis (Fig. 1). The tunica propriya was prominent. The interstitium contained Leydig cells and fibroblast like elements.

\section{Busulphan treatment}

10 days

Seminiferous tubules failed to show much regressive change in this group. 

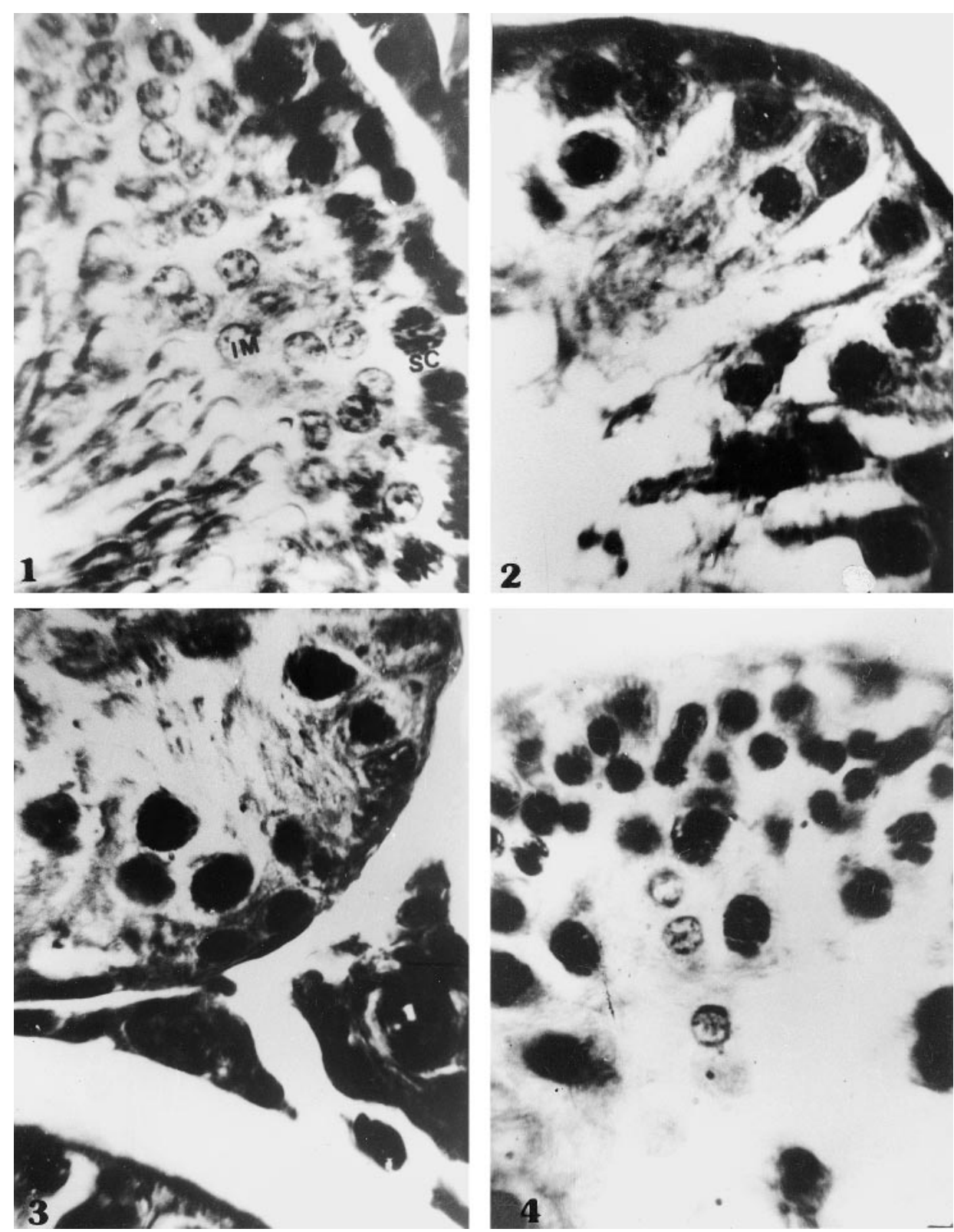

Fig. 1. Part of the seminiferous tubules ST (LM) of the control rat with stages VIII spermatid (IM) and spermatocyte (SC) observed at higher magnification $(\times 1000)$. Fig. 2. Section of testis of 40 days Busulphan post-treated rats. ST showing maturation depletion of post-Zygotene germ cells. Sertoli cells were normal $(\times 1000)$. Fig. 3. Section of testis of 40 days Busulphan post-treated rat showing few necrotic spermatogonia, early and late primary spermatocytes and normal Leydig and Sertoli cells $(\times 1000)$. Fig. 4. Higher magnification of a tubule showing development of few secondary spermatocytes at 70 days of Busulphan post-treatment $(\times 1000)$ 
Table 1

Effect of Busulphan $(10 \mathrm{mg} / \mathrm{kg}$ body weight) on the relative weights of testis, accessory sex organs of adult male Indian house rats (Rattus rattus)

\begin{tabular}{lccccccc}
\hline & & \multicolumn{5}{c}{ Relative weight $(\mathrm{mg} / 100$ gm body wt.) } \\
\cline { 5 - 8 } Group & $\begin{array}{c}\text { Body wt. } \\
\text { (gm.) }\end{array}$ & Testis & Epididymis & Vas deferens & $\begin{array}{c}\text { Seminal } \\
\text { vesicle }\end{array}$ & $\begin{array}{c}\text { Coagulating } \\
\text { gland }\end{array}$ & $\begin{array}{c}\text { Ventral } \\
\text { prostate }\end{array}$ \\
\hline Control (5) & $117.40 \pm 11.40^{* *}$ & $1166.54 \pm 28.30$ & $462.60 \pm 21.40$ & $45.27 \pm 7.9$ & 221.832 .3 & $76.3 \pm 18.2$ & $330.816 \pm 19.26$ \\
10 days (5)* & $118.40 \pm 11.94$ & $1146.84 \pm 21.46$ & $456.60 \pm 26.80$ & $44.37 \pm 9.50$ & $229.00 \pm 37.90$ & $78.4 \pm 19.6$ & $352.58 \pm 16.54$ \\
40 days (5) & $119.80 \pm 11.23$ & $767.00 \pm 31.34^{\mathrm{e}}$ & $360.40 \pm 12.50^{\mathrm{e}}$ & $44.42 \pm 11.49$ & $215.00 \pm 32.99$ & $61.20 \pm 15.60$ & $348.92 \pm 11.47$ \\
70 days (5) & $116.30 \pm 4.60$ & $640.20 \pm 28.76^{\mathrm{e}}$ & $252.30 \pm 25.86^{\mathrm{e}}$ & $36.60 \pm 12.06$ & $264.50 \pm 19.35$ & $50.00 \pm 16.40$ & $348.52 \pm 20.33$ \\
100 days (5) & $124.20 \pm 6.18$ & $1069.34 \pm 24.35$ & $441.30 \pm 31.81$ & $44.31 \pm 8.70$ & $223.20 \pm 38.80$ & $78.60 \pm 19.40$ & $311.10 \pm 17.79$ \\
\hline
\end{tabular}

ef animals in each group.

**Mean \pm Standard error.

eSignificant at $\mathrm{P}<0.001$. 
40 days

At this stage a drastic regressive effect on the testis was observed. The seminiferous tubular diameter was significantly reduced and in most cases, the tubular lumen obliterated. The tubules were largely devoid of spermatoza and the spermatogenic stages. Spermatogenic cells were being sloughed off into the tubular lumen (Figs 2 and 3). Tubules showed an increase in amorphous cell debries along with hyperplasia of the interstitium. The primary germ cells in the adluminal compartment and the interstitial Leydig cells appeared normal.

70 days

At 70 days the seminiferous tubular diameter was increased. The tubules were still devoid of pachytene spermatocytes, spermatids and spermatozoa. Due to shrinkage of the tubules the interstitium appeared conspicuous but the Leydig cells appeared normal. Repopulation of type A and type B spermatogonia, resting and Zygotene spermatocytes (Fig. 4) occurred in most of the tubules. Tubules contained normal peripheral Sertoli cells.

100 days

At 100 days of post-treatment, the tubular diameter was further increased. Active spermatogenesis was observed in majority of the tubules. Various cellular associa-

Table 2

Gonosomatic index, spermatogenesis index, seminiferous tubular diameter and Leydig cell nuclear diameter in various groups of busulphan treated adult male wild Indian house rat (Rattus rattus)

\begin{tabular}{lcccc}
\hline Group & $\begin{array}{c}\text { Gonosomatic } \\
\text { index }\end{array}$ & $\begin{array}{c}\text { Spermatogenesis } \\
\text { index }\end{array}$ & $\begin{array}{c}\text { Seminiferous } \\
\text { tubular } \\
\text { diameter }(\mu \mathrm{m})\end{array}$ & $\begin{array}{c}\text { Leydig cell } \\
\text { nuclear } \\
\text { diameter }(\mu \mathrm{m})\end{array}$ \\
\hline Control (5)* & $1169.7 \pm 21.00^{* *}$ & $90.80 \pm 2.16$ & $175.73 \pm 6.20$ & $5.86 \pm 0.26$ \\
10 Days (5) & $1142.30 \pm 22.00$ & $89.40 \pm 1.75$ & $170.40 \pm 8.50$ & $5.78 \pm 0.08$ \\
40 Days (5) & $775.00 \pm 21.00^{\mathrm{e}}$ & $43.82 \pm 6.74^{\mathrm{e}}$ & $115.52 \pm 18.20^{\mathrm{e}}$ & $5.91 \pm 0.12$ \\
70 Days (5) & $646.00 \pm 22.00^{\mathrm{e}}$ & 0 & $145.38 \pm 14.50^{\mathrm{c}}$ & $5.94 \pm 0.09$ \\
100 Days (5) & $1070.20 \pm 25.00^{\mathrm{b}}$ & $81.80 \pm 3.15$ & $161.00 \pm 6.95$ & $5.84 \pm 0.08$ \\
\hline
\end{tabular}

*Number of animals in each group.

**Mean \pm standard error.

$\mathrm{b}$ Significant at $\mathrm{P}<0.02$.

c Significant at $\mathrm{P}<0.01$.

e Significant at $\mathrm{P}<0.001$.

The data without superscript are not significant.

Acta Biologica Hungarica 52, 2001 
tions regained their normal profile. Sertoli and interstitial cells remained unchanged in morphology and number.

Gonosomatic index, spermatogenetic index, seminiferous tubular diameter and Leydig cell nuclear diameter

CONTROL. The gonosomatic index (i.e. paired testis wt., $\mathrm{mg}$, in relation to $100 \mathrm{gm}$ body wt.) in the untreated animals ranged from 1148 to 1190 and spermatogenesis index was about 90.8 (Table 2).

\section{Treatment groups}

There was no marked decrease in the values of the gonosomatic index and spermatogenetic index in the 10 days busulphan post-treated animals.

The gonosomatic and spermatogenetic index were lowered progressively at 40 $(<.001)$ and $70(<.001)$ days of busulphan post-treatment (Fig. 5). At 70 days the index value was reduced to zero.

However, the gonosomatic as well as spermatogenetic index showed a conspicuous increase at 100 days of busulphan post-treatment. These features lead towards normalcy.

Seminiferous tubular diameter reduced in the 40th $(\mathrm{P}<.001)$ and 70 th $(\mathrm{P}<.01)$ days busulphan post-treated animals (Fig. 6) in comparison to the control value (approx. $176 \mu \mathrm{m}$ ). There was no remarkable change in the Leydig cell nuclear diameter.

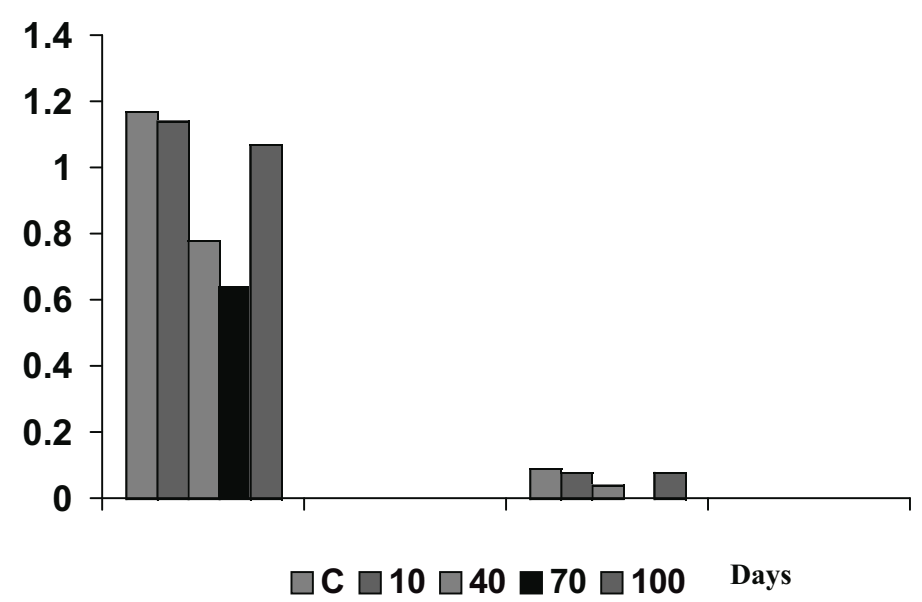

Fig. 5. Gonosomatic index (G. Index) and Spermatogenetic index (Spt. Index) in control and Busulphan treated rats $(10 \mathrm{mg} / \mathrm{kg}$. Body wt.) at various time intervals 


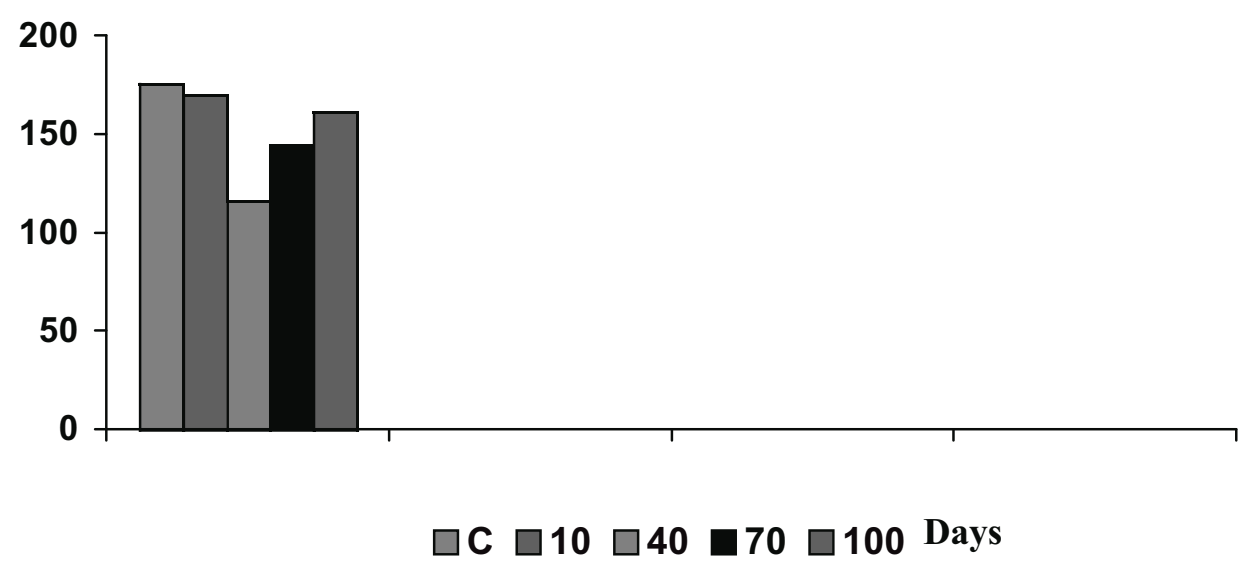

Fig. 6. Seminiferous tubular diameter $(\mu \mathrm{m})$ in control and Busulphan treated rats $(10 \mathrm{mg} / \mathrm{kg}$ body wt.) at various time intervals

\section{Libido}

The effect of busulphan treatment on sexual behaviour and mating were examined in separate successive experiments. The behavioural observations indicated that the busulphan treated males exhibited no marked alterations in the frequency of sexual advances in relation to the untreated animals.

\section{Histochemical components}

\section{Control group}

Amongst the enzymes related to androgen formation, $\Delta 53 \beta-\mathrm{HSDH}, 17 \beta-\mathrm{HSDH}$ were histochemically demonstrable within the interstitial and Sertoli cells region of the testes of Rattus rattus. They were in the form of diformazan granules. Alkaline phosphatase activity was found mainly in the basement membrane of the seminiferous tubules (BMST) and Leydig cells. Intensity of acid phosphatase activity was moderate within the testicular tissues.

Sudanophilic lipids were moderate in distribution. They were mainly present within the seminiferous tubules and interstitium. The coarse granules varied in size and were located irregularly at the periphery of the tubules. 


\section{Busulphan treatment}

No significant changes were observed in the 10 days post-treated animals.

At days 40 and 70 of busulphan post-treatment, intensity of lipid components was increased in the interstitium. There was no marked variation in the intensities of $3 \beta$ HSDH (using DHA as the substrate) and 17 $\beta-\mathrm{HSDH}$ (using estradiol as the substrate) in all the treatment groups investigated. Acid phosphatase activity was quite feeble in the 40th and 70th day busulphan post-treated groups. There was no change of alkaline phosphatase activity in all the experimental groups.

\section{DISCUSSION}

The present experimental results clearly revealed that Busulphan (Myleran), possessed antispermatogenic activity and it acted on the seminiferous tubular compartment and spermatogenesis. Due to its administration, the testicular weight was severely decreased and no adverse effect on the body and other vital organs weight were recorded.

Histological changes were apparent by the significant reduction of the seminiferous tubules, cytotoxic and cytolytic manifestations of all the spermatogonial cells including spermatogonia. At the same time there was no morphological change of the Leydig cells and Sertoli cells due to the same treatment. Quantitative histological study of the seminiferous tubules of the treated animals revealed the arrest of spermatogenesis at various stages and severe decline in the population density of late primary spermatocytes, spermatids and spermatozoa. This action may be due to the suppression of spermatogonial cell division and the arrest of spermatogenesis at the Zygotene stage. It is assumed that it may be due to the maturation blockages at this stage [12]. In Golden hamster, B spermatogonia is also sensitive to Myleran while in mouse and rat it is resistant [31].

It was estimated that the testicular phases of spermatogenesis in rat (Sherman species) require exactly 48 days [7], of which 27 days are required for the conversion of Type A spermatogonia into spermatocytes in diakinesis stage [7]. Jackson et al. [12] pointed out that Busulphan acts more selectively on early spermatogonia with sterility commencing about 50-60 days after dosing in rats. This data is also consistent with the present findings in Rattus rattus also, where the cauda epididymis and vas deferens comprises no normal spermatozoa by 70th days and repopulation within the seminiferous tubules was evident on 100th day of post-treatment. There were some documented evidences also of the degenerative effect of Busulphan on the testis of pigeon [2], common myna [17], quail [16] and parakeet [27].

Histochemical evidences of certain components clearly indicated that there was an apparent increase in overall lipid contents in the testes as depicted from the histochemical profile of Busulphan treated animals. Similar features were also observed in the Busulphan treated gerbil testes [33]. However, Kar et al. [19] reported a decrease in concentration of lipids in the isolated rat seminiferous tubules. 
The decrease in activity of acid phosphatase in the testes at days 40 and 70 can be supposed to be brought about with the depletion of cell population of the seminiferous tubules of the treated rats. Earlier studies have shown that the alteration in the activities of testicular phosphatase can be reflected with the suppression of functional changes in the testicular cell types [8, 11, 23, 34].

Intense activity of alkaline phosphatase enzymes at 40 days of post-treatment may be due to the shrinkage of the tubular components of the testis and is in conformity with the findings of Singh and Mathur [33], Ahlquist [1].

Histochemical visualization of the hydroxysteroid dehydrogenase (HSDH)

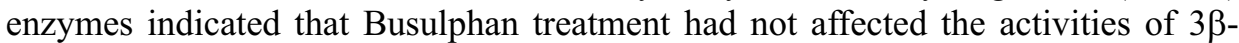
$\mathrm{HSDH}$ and $17 \beta-\mathrm{HSDH}$ in the interstitium. The Leydig cells remained structurally as well as functionally normal, suggests that the testosterone secreting ability in the testis is generally normal, even when thay lack spermatogenic cells. Although Niimura et al. [26] recently pointed to a shifting of $3 \beta$-HSDH activity from Leydig to Sertoli cells in Busulphan treated rat testis without altering the testosterone secreting ability. No such feature could be visualized in the present study. But altered steroid metabolism could be manifested, from strong histochemically localized $\Delta 5$ $3 \beta-\mathrm{HSDH}$ and $17 \beta-\mathrm{HSDH}$ enzymes in the cultured Sertoli cells from germ cells depleted (Busulphan treated) animals and moderate activity in the intact ones [18].

Serial mating performance test indicated that Busulphan induced acute testicular regression associated with a severe depletion of sperm count and resulted in sterility for a specific period. The sexual behaviour suggested unimpaired libido.

In the present study unaltered testicular steroidogenesis had been observed due to Busulphan administration. Such a suppressive effect of Busulphan on testicular spermatogenesis in the absence of any apparent change in the libido suggest that the drug directly acted on the seminiferous tubules. The result was also consistent with the findings of Jackson et al. [14]; Jackson and Craig [15]. Although the present experimental results pointed out the direct action of Busulphan on the seminiferous tubules but it was not very unlikely that this drug mediated its action at the pituitary level. Kar et al. [19] in a more detailed study in the rats, Saha and Ghosh [32] in the Silver munia and Nandy [27] in the rose-ringed parakeet pointed out that the antispermatogenic action of Busulphan was possibly mediated through the pituitary-gonadal axis.

Definite answer to the question whether Busulphan exerts its action at the pituitary level in Rattus sp., is still difficult to interprete in the present experiment as the study had not been conducted to correlate it with the circulatory levels of extratesticular androgens. But the possibility of any direct inhibitory effect of the drug on the responsiveness of the tubules to circulating FSH levels cannot be ruled out.

\section{ACKNOWLEDGEMENT}

This work was supported by financial assistance from a CSIR sponsored project, No. 38 (708)/90-EMR-II/, Government of India. 


\section{REFERENCES}

1. Ahlquist, K. A. (1966) Enzyme changes in rat testis produced by the administration of Busulphan and of 7, 12 - dimethylbenz (a) anthracene. J. Reprod. Fert. 12, 377-379.

2. Arbeiter, K., Hager, G., Kopschitz, M. M. (1975) Temporary sterilization of domestic pigeon that have become feral. Zentralbl. Verterinaermed Reihe A. 22, 117-141.

3. Bilaspuri, G. S., Guraya, S. S. (1984) Histochemical studies on steroid dehydrogenases in the testis of the goat (Capra hircus). J. Endocrinol. 101, 359-363.

4. Bitensky, L. (1963) Modifications of the Gomori acid phosphatase technique for controlled temperature frozen sections. Quart. J. Micros. Sci. 104, 193-196.

5. Bollag, W. (1953) Der Influss van Myleran auf die Keimdrüsen von Ratten. Experientia 9, 26.

6. Butcher, R. G., Chayen, J. (1966) Quantitative studies on the alkaline phosphatase reaction. J. Roy. Micros. Soc. 85, 111-117.

7. Clermont, Y., Leblond, C. P., Meesler, B. (1959) Duree du cycle de l'epithelium seminal du rat. Arch. Anat. Microscop. Morphol. Exptl. 48, 37-56.

8. Delhumeau-Ongay, G., Trejo-Bayonara, R., Alvarez-Buyalla, R., Lare-Vivas, L. (1973) Increase of $\left(\mathrm{Ca}^{2+}-\mathrm{Mg}^{2+}\right)$-adenosine triphosphatase activity in rat testis undergoing regression of the germinal epithelium. J. Reprod. Fertil. 34, 149-153.

9. Fischer, R. A. (1963) Statistical methods for research workers. Oliver Boyd. London.

10. Fox, B. W., Jackson, H., Craig, A. W., Glover, T. D. (1963) Effects of alkylating agents on spermatogenesis in the rabbit. J. Reprod. Fertil. 5, 13-22.

11. Guha, K., Vanha-Perttula, T. (1980) Acid phosphatase in human testis after prolonged estrogen treatment. Andrologia, 12, 252-260.

12. Jackson, H. (1959) Antifertility substances. Pharmacol. Rev. 11, 135-172.

13. Jackson, H. (1966) Antifertility compounds in the male and female. Thomas, Spring field. Illinois.

14. Jackson, H., Partington, M., Fox, B. W. (1962) Effect of "Busulphan" (Myleran) on the spermatogenic cell population of the rat testis. Nature 194, 1184-1185.

15. Jackson, H., Craig, A. W. (1969) Effects of alkylating chemicals on reproductive cells. Ann. N. Y. Acad. Sci. 160, 215-227.

16. Jones, P., Jackson, H. (1972) Effects of duration of spermatogenesis in Japanese quail, Coturnix coturnix japonica, using antispermatogonial chemicals. J. Reprod. Fertil. 31, 319-322.

17. Kanwar, U., Sheikhar, C., Jhamb, A. (1977) Effect of Busulphan on the testis of myna, Acridotheres tristis. Ind. J. Exp. Biol. 15, 68-69.

18. Kanzaki, M., Niimura, S., Ishida, K. (1992) Histochemical studies on steroid metabolism in cultured cells from the germ cell - depleted rat testis. Niigata Daiqaku Noqakubu Kenkyu Hokoku. 44, 1-7.

19. Kar, A. B., Jehan, Q., Kamboj, V. P., Chowdhury, S. R., Chowdhury, A. R. (1968) Effect of busulphan on biochemical composition of the rat seminiferous tubules. Ind. J. Exp. Biol. 6, 9-12.

20. Kasuga, F., Takahashi, M. (1986) The endocrine function of rat gonads with reduced number of germ cells following Busulphan treatment. Endocrinol. Jpn. 33, 105-115.

21. Kay, W. W., Whitehead, R. (1941) Sudhan III and IV methods for netural fats. In: Pearse, A. G. E. (ed.): Histochemistry Theoretical and Applied 2nd Edition. Little Brown and Co., Boston pp. 853-854.

22. Maitra, S. K., Ghosh, A. (1981) Gonadal response to testosterone propionate during breeding and post-breeding phases in the male blossomheaded parakeet. Psittacula cyanocephala (Aves: Psittaciformes). Aust. J. Zool. 29, 853-859.

23. Males, J. I., Turkington, R. W. (1971) Hormonal control of lysosomal enzymes during spermatogenesis in rat. Endocrinol. 88, 579-588.

24. Monoyer, J. (1962) Alterations dela spermatogenese chez des rats traits parle Myleran. Comp. Rend. Soc. Biol. 156, 968-970.

25. Morris, I. D., Bardin, C. W., Musto, N. A., Thau, R. B., Gunsalus, G. I. (1987) Evidence suggesting that germ cells influence the bidirectional secretion of androgen binding protein by the seminiferous epithelium demonstrated by selective impairment of spermatogenesis with Busulphan. Int. J. Androl. 10, 691-700 
26. Niimura, S., Tanaka, M., Ishida, K. (1990) Histological observations of hydroxysteroid dehydrogenase activity and testosterone secreting ability in busulphan injected rat testes. Bulletin of the faculty of Agriculture, Nigata University, No. 42, 81-88.

27. Nandy, P. (1993) Histophysiological study of male reproductive organs of two common Indian pest birds with special reference to their control of fertility. Ph. D. Thesis., Kalyani University.

28. Patzner, R. A. (1977) Cyclic changes in the testis of the hagfish, Eptatretus burgeri (cyclostomata). Acta Zool. (Stockh) 58, 223-226.

29. Patzner, R. A., Ichikawa, T. (1977) Effects of hypophysectomy on the testis of hagfish, Eptatretus burgeri Girad (cyclostomata). Zool. Anz. (Jena) 199, 371-380.

30. Pearson, B., Grose, F. (1959) Histochemical demonstration of 17- $\beta$ hydroxysteriod dehydrogenase by use of a tetrazolium salt. Proc. Soc. Exptl. Biol. Med. 100, 636-638.

31. Rommerts, F. F., Grootenhuis, A. J., Hoogerbrugge, J. W., Vander Molen, H. J. (1985) Ethane dimethane sulphonate (EDS) specifically inhibits LH stimulated steroidogenesis in Leydig cells isolated from mature rats but not in cells from immature rats. Mol. Cell. Endocrinol. 42(2), 105-111.

32. Saha, S., Ghosh, A. (1982) Effect of Busulphan on the testis of a finch, Lonchura malabarica. Arch. Biol. (Bruxelles) 93, 343-352.

33. Singh, K., Mathur, R. S. (1968) Enzyme changes in the gerbil testis produced by the administration of an alkylating agent Busulphan (Myleran, 1, 4, dimethane-sulphonoxybutane). Acta Anat. 71, $472-480$.

34. Tice, L. W., Barnett, R. J. (1963) The fine structural localization of some testicular phosphatases. Anat. Rec. 147, 43-63.

35. Wattenberg, I. W. (1958) Microscopic histochemical demonstration of steroid $3 \beta$-ol dehydrogenase in tissue section. J. Histochem. Cytochem. 6, 225-232. 